\title{
D Rocrama de estudos e pEsquisas EM REForma do ESTADO E GOVERNANÇA
}

\section{Fundaçāo Getúlio Vargas / Escola Brasileira de Administraçāo Pública*}

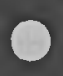

Estado brasileiro vem passando por transformaçōes profundas, detcrminadas por mudanças internas c também pelas alecraçoes na economia mundial.

O processo de democratização inaugurado nos anos 80 consagrou, na Constituição de 1988 um novo formato do Estado, no que diz respeito à universalizaçāo das políticas sociais, à descentralizaçāo das estruturas institucionais c dos recursos fiscais a novas formas de controle social.

O esgotamento do modelo de substituiçảo de importaçōes somou-sc as profundas iransformaçōes ocorridas como decorréncia da implantação de um novo paradigma tccnológico e da globalização da cconomia.

Novas formas de organizaçāo da produção, caracterizadas pela elevada incorporação tecnológica e a flexibilizaçāo das relaçōes de trabalho têm levado à busca de insirumentos gerenciais que assegurem a eficiéncia c a qualidade dos scrviços.

A redução do papel produtivo do Fistado, com o deslocamento destas arribuiçōes para o mercado, ben como o surgimento de um terceiro setor - privado. porém cumprindo funçōes públicas - é uma rcalidade quc está redefinindo a relaçãc I:stado/Socicdade en todos os países do mundo.

Um listado que seja foric c estratégico, capaz de asscguraro cumprimento das funçōes públicas, bem como lutar pela redução das desigualdades sociais prevalecentes e ao mesmo tempo envidar esforços para buscar uma inserção vantajosa para o pais na economia nacional. Fista é a equação que está colocada para todos, mas cujas soluçōes estamos longe de divisar.

O esiudo da reforma do Estado ou das reformas - cm um periodo de tantas c tão vclo\%es mudanças, 
deve estar voltado para o fortalecimento da capacidade de governança em nossa socicdade c para os idcais de igualdade c justiça social.

Por considerar este tema de fundamental relevância, a ïGV/ I:BAP visa implantar o Programa de Estudos e Pesquisas sobre Reforma do Estado c Governança. Atualmente, o presente Programa é constiutúdo de cinco projetos de pesquisa, além de monografias referentes ao tema, quc objerivam possibilitar uma melhor análise da conjuntura politico-instifucional.

Os Projetos são os seguintes:

1 - Burocracia e Reforma do Estado

Este projeto tem como objetivo criar um sistema de informaçócs permanentes sobre as atitudes c crenças da burocracia diante dos desafios enfrentados na mudança do papel do Estado. na rede. finição das suas relaçōes com a socicdade, na implementaçāo de novos instrumentos de gestão e avaliação.

A reforma atual pela qual vem passando o Fistado tem tido como orientaçāo géral o redimensionamento do tamanho c funçóes do listado de forma a transferir para o mercado certas atividades anteriormente estatais, assim como introduzir na administraçāo pública instrumentos gerenciais que pemitam o aumento da ciciencia c qualidade de suas açōes. No entanto, todos os estudos tém desconsiderado, até o momento). como estas transformaçōes vêm afctando a burocracia ce alterando as condiçócs necessárias para preservar sua auronomia c cficiéncia na utilizaçāo de scus recursos técnicos, de forma que ela possa se situar de uma mancira pró-ativa nestc processo.

Scrá claborado um questionário fechado, contemplando as diferentes dimensöes relevantes na atual reforma do Kstado e nas mudanças relativas à atuação da burocracia estatal. De pois de prétestado. este questionário deverá ser automaticamcnte aplicado em cada uma das novas turmas que ingressarem nos cursos da EBAP.

Considerando que a EBAP tem um número anual de alunos superior a 5000, com diferentes inserçóes na burocracia pública. tercmos a oportunidade permancntc de atualizar as informaçóes sobre as mudanças de atitudes c crenças dos funcionários do listado en relaçāo ao scu papel. 
2. Municipalização e Poder l.ocal

Estc projelo visa estudar as mudanças ocorridas a partir da municipaliza(َ̧́), no processo de gestäo dos sistemas municipais de saúde c analisar suas possiveis relaçóes com a configuraça co modo de funcionamento do sistema de poder local

A partir da Constituição de 1988. o Brasil vem vivendo um signilicarivo processo de descentralizaçấo político-adminisirativa, dentro de uma dimensão maior de democratizaçāo. A saúde foi a area da política social em que o modelo descentrallsador foi mais ampla e radicalmente aplicado. Mais de cinco anos de pois da implantaçäo de uma profunda reforma no arcabouço juridico normativo no sctor. näo sc conhecem as conscqüencias destas medidas nas possive is transformaçócs da eslera municipal. A partir du perfll dos aluais secretários municipais de saúde será possivel averiguar csta mudança.

Preicnde-se realizar um inquerito nacional, abrangendo a totalidadc dos municipios brasileiros. a partir de um questionário a ser respondido pelo responsável municipal pela saude. Os dados colerados ratarỉo da caracterização pessoal c profissional. das relaçóes politicas c instilucionais, das modalidades de gesiăo.

3. O (orporativismo. a Justiça do Trabalho c o Novo Sindicalismo

O presente projeto tem como objetivo cstudar as funçóes reguladora c normativa cla Justiça do Trabalho c as diferentes proposias de alteração da representaçäo classista, apresentadas seja pelo governo. seja por setores da sociedade.

A aluação da Justiça do 'Trabalho c um dos pilares do modelo corporaivo estaral das relaçoes classistas, introduzido na década de 40 c vigente até os dias atuais. As transformaçōes na organizaçio dos trabalhadores, as novas formas de organizaçäo da produção e a democratizaçāo das relaçóes sociais, requerem uma alicração substancial das formas de regulação do trabalho de forma a torna-la mais flexivel c condizcente com as demandas atuais. Fste ć um ponto crucial da reforma do Estado que merece ser analisado.

Para isto. serão excculadas uma pesquisa bibliográfica c entrevistas com membros da Justiça do Trabalho c com representantes sindicais c patronais 
4-Comparative Ilealth Policies in Latin America

O objetivo geral do projeto é estudar e comparar os processos correntes de descentralização e privatizaçāo nos sistemas de saúde da Argentina, Brasil e México e suas conseqüências no acesso aos serviços de saúde de diferentes segmentos da popu. laçào.

As mudanças das políticas de saúde que têm sido implantadias recentemente na América Latina têm direcionado a organização dos sistemas de atençāo à saúde em duas direçōes: desde o público para o privado e desde o nivel central para o nivel local. Até o momento os efeitos destas mudanças se realizaram em termos macro-analíticos, mas o teste final será realmente quando se puder afirmar o que elas representam efetivamente para usuário dos serviços de saúde.

O estudo será desenvolvido de forma similar e concomitante nos três países, de forma a permitir a comparaçāo dos resultados. Serāo utilizadas as seguintes modalidades de estudos:

- estudo quantizativo - adotando o modelo comportamental de Andersen, será realizado um survey, com populaçāo aberta, sobre utilização de serviços, tomando como condiçóes traçadoras a ocorréncia de diaberis mellitus, hipertensāo, fratura de membros, parto e pré. natal. Serāo investigados 130 individuos por "tracer".

- cstudo qualizativo - diagnóstico das principais características e alteraçōes da política e organizaçäo dos sistemas de saúde em cada um dos países.

- estudo antropológico - análise das representaçōes sociais dos usuárjos a fim de aprender a lógica de hierarquização das prioridades e definição das estratégias de utilização dos se rviços.

5. Gestāo Pública e Reforma do Estado: um estudo de caso do Hospital Geral de Fortaleza

O projeto visa documentar. analisar e divulgar a experiência de gestão pública do Hospital Geral de Fortaleza, buscando identificar as alte mativas criativas de gestāo de um hospital público e os limites impostos pelas regras atuais da administraçāo pública.

A reforma do Estado no setor saúde teve início com o processo de descentralização na década de 80. O foco atual de preocupaçóes é a gerência dos serviços complexos. As diferentes altemativas 
existentes evidenciaram uma polarização entre as dimensóes da autonomização e flexibilização, indicando quatro casos paradigmáticos: Hospital Sarah Kubitishel, Hospital das Clínicas de Porto Alegre, Instituto do Coração e Hospital (ieral de Foraleza. Apenas no último caso temos um exemplo de gestão bem sucedida que se passa dentro da administraçāo pública.

Como metodologia será feita uma pesquisa de campo enfocando: processo decisório. recursos matc:riais, financeiros $c$ humanos, sistemas de custos, avaliação e controle de qualidadc, participação controle social.

* Realização: Escola Brasileira de Administração Pública EBAP/RGV

(Coordenação de Programa: Sonia Fleury). 